\title{
Deep conceptual learning opportunities in business studies classrooms
}

\section{Devika Naidoo}

Department of Education and Curriculum Studies, University of Johannesburg, Johannesburg, South Africa devikan@uj.ac.za

https://orcid.org/0000-0001-7725-0540

\section{Mbali Mabaso}

University of Johannesburg, Johannesburg, South Africa

200573319@student.uj.ac.za

(Received: 21 March 2020; accepted: 19 October 2020)

\section{Abstract}

Initial tests of the curriculum design coherence model (McPhail, 2020) indicate that teachers face challenges in relation to engaging deeply with the epistemic structure of their subject. In this study, we discuss the additional difficulty that teachers have in identifying appropriate content and examples that will provide opportunities for students' concept formation. The key question guiding this study was: "What opportunities for deep conceptual learning and cognitive advance are provided in business studies classrooms?" This analysis of the pedagogic practices of teachers is framed by the curriculum design coherence model (CDC) that is informed by deep learning from the cognitivist theory perspective. This article gives an account of observations of grade 11 business studies lessons in two schools. The lessons were observed, recorded, transcribed, and deductively analysed according to an analytical framework based on the CDC model. While there was evidence of concepts that were taught, appropriate subject content necessary for understanding the concept was not evident in most of the lessons. The dominant pedagogy of direct instruction, reading definitions, and copying notes amounted to giving students the definition of concepts and their basic components in a skeletal way. Content that requires students to analyse and infer meanings and make generalisations was lacking. The absence of appropriate content and examples, such as case studies in the textbook, curtailed opportunities for deep conceptual learning and cognitive advance. These practices deny learners access to the formal academic knowledge of the discipline.

Keywords: deep learning, concept formation, epistemic structure, business studies, curriculum design coherence model 


\section{Introduction}

The Curriculum and Assessment Policy Statement (CAPS) for business studies (2011) has outlined the significance of both knowledge and skills. It aims at the "attainment and application of business knowledge, skills, and principles to productively and profitably conduct business in changing business environments" (DBE, 2011, p. 8) and developing learners who will be capable of identifying business opportunities, take calculated risks, sustain employment in the competitive world of work and start their own businesses to reduce unemployment in their societies. It prescribes domain specific subject knowledge to be taught, through which students would acquire skills. It foregrounds the attainment and application of knowledge and skills. It consists of four main topics which are Business Environments, Business Ventures, Business Roles, and Business Operations (Department of Basic Education, 2011). Muhle (2014) has noted that the aim of business studies is to develop valuable skills in learners to enable them to solve a business problem creatively in the business world.

Researchers working on the business studies CAPS have focused on pedagogy (Muhle 2014; Sithole, 2018; Sithole \& Lumadi 2012) problem solving (Meintjes et al., 2015) and assessment for learning (Gouws \& Russell, 2013). Sithole and Lumadi (2012) found that business studies teachers in Botswana were facing challenges related to teaching the subject matter and experienced constraints in using entrepreneurial pedagogies. Meintjies et al. (2015) made a case for teaching problem-solving in business studies at secondary school level. They noted that although the high unemployment rate in South Africa compels potential entrepreneurs to start their own businesses in order to survive, there is little or no formal training or education in entrepreneurship. Gouws and Russel (2013) focussed on CAPS assessment and described how to prepare teachers of business studies to practise assessment that supports learning. Researching the pedagogical orientation of physical science teachers, Ramnarian (2014) found that teachers at township schools have a strong active direct teaching orientation overall, while teachers at suburban schools exhibit a guided inquiry orientation, with concepts being developed via a guided exploration phase.

However, there is a dearth of knowledge in the area concerned with deep conceptual learning opportunities in the business studies classroom. Deep conceptual learning is the mainstay of higher order thinking skills such as inference, generalisation, application in new contexts, and critical thinking. Marzano (2010) argued that although thinking and reasoning processes, such as problem solving and decision making, are not new skills, what is new in the last 20 years is that we have become aware that some cognitive processes are foundational to higher order thinking and that inference is one of these foundational processes.

In this study, we focus on the question: "What opportunities for deep conceptual learning and cognitive advance are provided in business studies classrooms?" It is framed by the CDC model that is based on deep learning from the standpoint of cognitivist theory (McPhail, 2020). McPhail pointed out that the emphasis in the CDC model is on curriculum design and not pedagogy. In our research we analysed the pedagogic practices of the teachers according 
to the CDC model. To teach for deep learning teachers must master the skill of identifying the key concepts to be taught in a particular topic and develop meaningful ways to help the learners engage with those concepts and to scaffold the learning. Thus, all teachers need pedagogical skills to enable them to theorise the content, key concepts, and skills to be taught. Having pedagogical skills is necessary if teachers are to be able to anticipate problematic areas in the content and invent creative pedagogical approaches to scaffold the learning processes of each learner (Shulman, 1986).

\section{Deep conceptual learning}

The view that deep learning rather than surface learning of information, facts, and formulas should be the aim of education (McPhail, 2020) comes closest to articulating the purpose of education as expounded by Tyler (1949). While experts in the field of 21 st century skills and the cognitive science literature concur that deep learning should be the aim of education, they differ on the knowledge or curriculum that will enable this. The 21 st century skills approach suggests that through learning about real-world problems and acquiring interdisciplinary knowledge, deep learning will occur while the cognitive science literature holds that deep learning occurs when domain specific subject knowledge is the starting point for curriculum design. "Deep learning requires understanding the related concepts within the overall systems of meaning and the curricular design needs to reflect the logic of the discipline on which it draws" (Rata (2016) cited in McPhail (2020, p. 5).

The ability to transfer knowledge to new situations or to apply knowledge in different contexts arises from deep conceptual learning. Thus, Jensen and Nickelsen (2008) have defined deep learning as learning that sticks; it is said to have occurred if the learner comes to understand concepts and is able to apply that conceptual knowledge in different contexts. Ark and Schneider (2016) of the Hewlett foundation also see skills and competencies as arising from a deep understanding of academic content that is used for problem solving in the classroom and in job contexts. Deep learning is defined as an

umbrella term for the skills, dispositions, and knowledge that students must possess to succeed in 21 st century jobs and civic life. At its heart is a set of competencies students must master to develop a keen understanding of academic content and apply their knowledge to problems in the classroom and on the job. (William and Flora Hewlett Foundation's Education Program, 2013, p. 9)

For Vygotsky (1978, cited by McPhail, 2020), learning is the gradually developed ability to think conceptually and apply conceptual thinking in various contexts including the sociocultural world. Hattie and Donoghue (2016) understood deep learning to mean "pursuing meaning, encompassing ideas, searching for patterns and underlying principles, and evaluating conclusions while examining arguments carefully, and, most importantly, becoming actively interested in subject knowledge" (p. 3).

A number of researchers have investigated ways in which deep conceptual learning could be facilitated. The well-known so-called lecture method has been shown to be ineffective 
(Aamna, 2017). In this study Aamna compared a concept formation teaching model to the lecture method of teaching. The concept formation teaching model was found to be more effective than the lecture method for clarifying and strengthening concepts.

Peer teaching has been found to be effective for learning concepts (Albert \& Van Der Mark, 1981). Bender and Schreiber (1980) proposed a didactic principle that they called the principle of operative concept formation. They noted further that the traditional instruction for concept formation by definition (language), by giving examples (intuition), and by drawing (construction) were pedagogically and epistemologically problematic.

Students form a clear understanding of a concept by studying examples of it. Parker (2020) distinguished deep conceptual learning about a concept from superficial knowledge of the vocabulary words associated with it. According to Parker (2020),

[w] hen a student forms a concept from its examples, he or she knows more than the definition of a term (e.g., river: he or she also knows some vivid examples of the concept that add flesh to a bare-bones definition, such as the Mississippi, the Amazon, the Yangtze and the Volga. (p. 1)

Pedagogy that supports concept formation, according to Parker, includes "an inductive teaching strategy that helps students form a clear understanding of a concept (or idea) through studying a small set of examples of the concept" (2020, p. 1).

Writing about physics, Aufschnaiter and Rogge (2012) differentiated between knowledge that is tied to particular objects and situations (such as descriptions and labels) and conceptual knowledge that refers to the commonalities of several objects and situations, known as context-independent knowledge in Bernstein's (2000) theory. According to Parker (2020), a concept is defined by critical characteristics shared by all examples of the concept. He explained,

For something to be an example of a concept, it must contain all these critical characteristics. To help students form the concept, the teacher helps them first to see these critical characteristics across different examples and, then to summarize those characteristics in a definition that students themselves write. (p. 1)

McPhail (2020) proposed a CDC model, based on deep learning as defined by cognitivist theory, that requires coherence and connection across subject concepts, subject content, pedagogy, subject competencies, and assessment. The CDC model arose out of a research project that investigated the challenges faced by first-year engineering students in a concept rich electrical engineering course (Collis et al., 2017). They found that students were able to apply formulae and accurately calculate circuit properties but because they did not understand what the word circuit means they were unable to generalise to new contexts.

The CDC model is underpinned by a social realist ontology that the world exists independently from our knowledge of it. The model draws on cognitive theory and hypothesises that subject concepts and epistemic structure (which, according to Bernstein 
(1999), refers to the unique vertical or horizontal structure of academic knowledge) are the basis of deep learning. McPhail (2020) proposed a CDC model that requires coherence and connection across subject concepts, subject content, subject competencies, pedagogy, and assessment. The model was tested by primary and secondary school teachers in New Zealand and England; initial findings indicated challenges for teachers in engaging deeply with the epistemic structure of their subject (McPhail, 2020). In this study, we note the additional difficulty that teachers have in identifying appropriate content and examples that will provide opportunities for students' concept formation.

\section{The curriculum design coherence model}

The CDC model hypothesises that for deep learning to occur subject concepts and the subject's epistemic structure ought to be the focus of curriculum design and ought to be made visible by teachers in their pedagogy. The model is based on four elements: select and sequence the subject concepts; connect concepts to content; connect knowledge-that to knowledge-how; and evaluate knowledge-that and knowledge-how.

\section{Select and sequence the subject concepts}

The starting place for curriculum design is disciplinary propositions and concepts (McPhail, 2020). All curriculum topics are underpinned by key propositions and concepts. The relationship of the concept to other concepts within the epistemic structure of the subject topic must be borne in mind. McPhail (2020, p. 7) advised that the next step is that "the design must make visible the interconnections of concepts within the topic because a concept acquires its meaning in relation to other concepts within the epistemic structure" of the discipline. Beginning a lesson plan with concepts is important since this supports the interrelationship between context-dependent knowledge and generalising or contextindependent knowledge (Bernstein, 2000). Concerning knowledge-that (KT), the students' deep learning depends on gradual awareness of inferential relationships within the whole system of meaning and the connection to procedural knowledge or knowledge-how (KH). The teaching sequence will also be derived from the newly formed inferential relations because, as Marzano (2010) explained, "Helping students understand when information is implied, or not directly stated, will improve their skill in drawing conclusions and making inferences. Inferencing is considered a foundational skill and a prerequisite for higher order thinking and 21st century skills" (p. 80).

The ability to make inferences is, in simple terms, the ability to use two or more pieces of information from a text in order to arrive at a conclusion (Kispal, 2008). To promote inferential connections the teacher needs to identify introductory concepts and connect them to related concepts in the current topic in a discipline.

\section{Connect concepts to content}

The second element establishes the distinction between subject concepts and subject content. Identifying appropriate content and examples that enable understanding of the concept is the 
second element of the model. McPhail (2020, p. 18) suggests three criteria for selecting content.

- Identify appropriate content material and examples to best clarify the meaning of concepts.

- Include context of the concept or content about the history of knowledge production to show that ideas are always provisional and subject to challenge and change because they are created by people in academic and practice communities.

- Question whether the selected material is in the social and political interests of students and society.

McPhail (2020, p. 18) emphasised the importance of content since it helps accelerate the cognitive development of students and it is "the raw material for the development of conceptual understanding" (p. 18).

\section{Connect knowledge-that (KT) to knowledge-how (KH)}

The third element of design is connecting KT (concepts and propositional knowledge) to KH to enable learners to use or apply that knowledge. It includes performance competencies and judgement competencies. "Performance competencies refer to the skills used to apply 'rules' in practice and to the student's ability to assess the performance of those skills in terms of the quality of the performance" (McPhail, 2020, p. 8).

Judgement competencies lend themselves to solving practical or theoretical problems. They require students to know why something is the case. The activities selected by the teacher enable concept formation and learning about the epistemic structure of the subject. During the lesson design stage, the teacher must create a connection between $\mathrm{KT}$ and $\mathrm{KH}$. This, according to Winch (2017, cited in McPhail, 2020, p. 8) is "the move from knowledge acquisition to possession where the growing application of skills and techniques occur through the interplay of KT and KH." Connecting KT to KH includes giving students practice in specific skills and techniques during which they apply KT to do the activities. In this way students are provided with opportunities to show that they understand the concept.

McPhail (2020) further asserted that this collaboration between KT and KH is the foundation for deep learning and long-term retention of knowledge and competencies in a particular subject area. This understanding, according to McPhail, is classified as knowing why since the student questions the reason behind the acquisition of the specific knowledge or skill.

\section{Evaluate knowledge-that (KT) and knowledge-how (KH)}

This element of the model focusses on evaluating judgements or decisions made by the student. They are the "means by which the connection is made visible between the cohering components of the model-knowing that and knowing how to" (McPhail, 2020, p. 9). Deep learning requires the teacher to evaluate $\mathrm{KT}$ and $\mathrm{KH}$ through the competencies of content recall, skill and technique, intelligent know-how, and knowing why. Recall requires 
evaluating whether students remember the content. Knowing content together with memorising it is very important and must be constantly evaluated. This includes testing whether the student can master the facts, understand the concepts, make calculations, understand and use the vocabulary, and know the conventions of that particular academic subject. Evaluating skill and techniques shows whether students are able to apply formula and procedural rules to execute the task or solve problems. Intelligent knowing how and why is measured by the extent to which students know why they use a skill or a technique. Furthermore, the student's understanding of concepts can also be tested through generalisation and application of conceptual knowledge. Being able to offer justification of their application is also important since this indicates a higher level of understanding. The elements of the CDC model were developed further into an external language of description (Bernstein, 1996) to assist with lesson analysis.

\section{Methodology}

For this research, qualitative research methodology was most suitable because of its flexible research design that allows emergent contingencies to be accommodated during the research process as Thompson (2011) pointed out. According to Babbie and Mouton (2006, p. 53), qualitative research methods "stay close" to the research subject. In this study, we analysed teachers' classroom practices in relation to whether they offered opportunities for deep learning in their business studies classrooms.

We selected two schools in the Johannesburg North district in Gauteng for this study. The lower socio-economic status school (LSESS) is a non-fee-paying school mostly of black learners and a small number of coloured learners. Non-fee-paying schools are the poorest government schools. In addition to higher teacher-learner ratios ranging from one to fifty to one to sixty-five these schools are also not as well-resourced as the fee-paying school. This school, a middle socio-economic status school (MSESS), is a fee-paying former model C school currently catering for learners from different races. This well-resourced school has lower teacher-pupil ratios ranging from one to thirty to one to thirty-five.

In this study, we employed the purposive sampling technique. Purposive sampling allows researchers to select research participants who would be information-rich, so we selected teachers who had been teaching business studies for a few years.

The two teachers in the LSESS will be referred to as Teacher A (TA) and Teacher B (TB). The two teachers in the MSESS will be referred to as teacher C (TC) and teacher D (TD). The table below illustrates the biographic details of the teachers. 
Table 1: Biographic details of the teacher participants

\begin{tabular}{|l|l|l|l|}
\hline SES & $\begin{array}{l}\text { Number of years of } \\
\text { teaching business } \\
\text { studies }\end{array}$ & Qualification & Presently teaching \\
\hline LSESS TA & 12 & $\begin{array}{l}\text { Advanced certificate in } \\
\text { actuarial science and } \\
\text { diploma in special needs }\end{array}$ & Grade 11 and 12 \\
\hline LSESS TB & 9 & PGCE & Grade 10 and 11 \\
\hline MSESS TC & 4 & $\begin{array}{l}\text { BEd Leadership and } \\
\text { management } \\
\text { 6-month PD course by } \\
\text { department }\end{array}$ & Grade 11 and 12 \\
\hline MSESS TD & 8 & BEd & Grade 11 and 12 \\
\hline
\end{tabular}

For this article, data was collected through non-participant lesson observations since it allowed for what Cohen et al. (2011) have called authentic data from a natural setting.

The teachers chose the lesson that was to be observed. For this study, we planned to do three observations per teacher but were unable to observe the third lesson for two of the teachers because of school activities that included preparation for the fiscal grade 11 business studies competition. Nonetheless, the aim of the observation, to get a sense of deep conceptual learning opportunities, was achieved in the two lessons conducted by these two teachers that we were able to observe. During observations, one of the researchers sat unobtrusively at the back of the classroom and made notes on the pedagogical practices of the teacher and on the interactions that were happening in the classroom. The lessons were audio-recorded and compared with field notes later. All audio records were transcribed by one of the researchers and developed further from field notes to derive a written record of the lessons.

We deductively analysed the lesson observation transcripts according to the four elements and pedagogical processes of the CDC model. The table below shows the analytical framework developed from the CDC model that guided data analysis. We developed a data analysis spreadsheet that included an additional column for each lesson. We read each lesson transcript and examined it for evidence of each element of the CDC model. We identified dominant practices such as direct instruction, reading out aloud from the textbook, and copying notes that detracted from deep learning.

Table 2: Analytical framework

\begin{tabular}{|c|c|}
\hline \multicolumn{2}{|l|}{ Section A: Curriculum Design Coherence model } \\
\hline Element & Evidence in the lesson observation data of: \\
\hline $\begin{array}{l}\text { 1. } \begin{array}{l}\text { Select and } \\
\text { sequence the } \\
\text { concepts }\end{array} \\
\text { - }\end{array}$ & $\begin{array}{l}\text { selection, sequencing, and interconnection of subject concepts } \\
\text { opportunities for students to acquire gradual awareness of inferential } \\
\text { relationships within the whole system of meaning and the connection } \\
\text { to procedural knowledge or KH. }\end{array}$ \\
\hline
\end{tabular}




\begin{tabular}{|c|c|c|}
\hline & $\begin{array}{l}\text { Connect } \\
\text { concepts to } \\
\text { content }\end{array}$ & $\begin{array}{l}\text { - } \quad \text { appropriate content, examples, and illustrations } \\
\text { - } \quad \text { content about the history of knowledge production } \\
\text { - } \quad \text { content in the social and political interests of students and society }\end{array}$ \\
\hline 3. & $\begin{array}{l}\text { Connect } \\
\text { knowledge-that } \\
\text { to knowledge- } \\
\text { how }\end{array}$ & $\begin{array}{l}\text { - performance and judgement competencies in solving practical or } \\
\text { theoretical problems. } \\
\text { - } \text { students knowing-why something is the case. } \\
\text { activities that enable concept formation and learning the epistemic } \\
\text { structure of the subject. } \\
\text { giving students practice in specific skills and techniques where they } \\
\text { apply KT to do the activities. } \\
\text { providing students with opportunities to show that they understand the } \\
\text { concept. }\end{array}$ \\
\hline & $\begin{array}{l}\text { Evaluate } \\
\text { knowledge-that } \\
\text { and knowledge- } \\
\text { how }\end{array}$ & 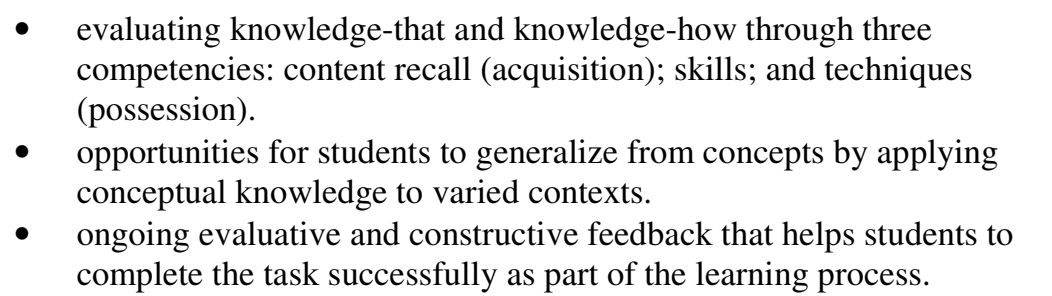 \\
\hline
\end{tabular}

We adhered to the ethical standards and procedures set out by the university. We applied for and obtained an ethical clearance certificate from the university ethics committee. We obtained approval to conduct research in these selected schools from the Gauteng Provincial Department of Education. We obtained signed consent letters from principals that granted us permission to conduct the research in both participating schools. We informed all the teacher participants about the purpose of the study and they consented to it. We assured all participants that their identities and responses would be kept confidential, and that their names would not be used anywhere in the study. Most importantly, we made sure that participants were fully aware of their right to withdraw from the study at any time. Finally, we informed the participants that the study would make recommendations for improvements in pedagogical practices of business studies teachers.

\section{Data analysis, presentation, and findings}

Table 3 below provides a summary of the analysis of lesson observation data according to the pedagogic processes advocated by the CDC model. Each aspect is elaborated on further in the sections that follow.

Table 3: Summary of data analysis

\begin{tabular}{|l|l|l|}
\hline $\begin{array}{l}\text { Pedagogic process as per CDC } \\
\text { model }\end{array}$ & Evident or not in 10 lessons & $\begin{array}{l}\text { Comments applicable to all 10 } \\
\text { lessons }\end{array}$ \\
\hline Selection of subject concepts & Evident in all 10 lessons & $\begin{array}{l}\text { Business studies concepts were being } \\
\text { taught }\end{array}$ \\
\hline Sequences concepts & Evident in all 10 lessons & Sequencing was evident as per policy \\
\hline Interconnects concepts & Evident in 1lesson & Surface interconnection \\
\hline Inferential relationships & Not evident in all 10 lessons & A telling or narrative pedagogy \\
\hline
\end{tabular}




\begin{tabular}{|l|l|l|}
\hline Connecting concept to content & Evident in 1lesson & Surface connection \\
\hline Selecting appropriate content & Evident in 1lesson & $\begin{array}{l}\text { One example in one lesson was given } \\
\text { by the teacher to enable learners' } \\
\text { understanding }\end{array}$ \\
\hline $\begin{array}{l}\text { Evidence of fallibility of } \\
\text { knowledge. History of knowledge }\end{array}$ & Not evident in all 10 lessons & $\begin{array}{l}\text { This component of enabling } \\
\text { understanding of the fallibility of } \\
\text { knowledge was not evident }\end{array}$ \\
\hline $\begin{array}{l}\text { Evidence of knowledge in the social } \\
\text { and political interest of students }\end{array}$ & Not evident in all 10 lessons & $\begin{array}{l}\text { There was no connection to } \\
\text { knowledge in the social and political } \\
\text { interest of students }\end{array}$ \\
\hline $\begin{array}{l}\text { Connection KT to KH Specific } \\
\text { methods and skills }\end{array}$ & Not evident in all 10 lessons & $\begin{array}{l}\text { Specific methods and skills not } \\
\text { practiced }\end{array}$ \\
\hline Validation of understanding & Not evident in all 10 lessons & Not evaluated \\
\hline Evaluation of KT and KH & Evident in all 10 lessons & Recall evaluated \\
\hline Evaluation of skill and technique & Not evident in all 10 lessons & Skill and techniques not evaluated \\
\hline $\begin{array}{l}\text { Evaluation of whether students } \\
\text { know why }\end{array}$ & Not evident in all 10 lessons & Intelligent knowing not evaluated \\
\hline
\end{tabular}

\section{Concept selection and sequencing}

All four teachers had identified business studies concepts and propositional knowledge to be taught to students. They were teaching the topic "entrepreneurship and social responsibility" from the section called "Business ventures and business roles" in the CAPS. While all the teachers were teaching the concepts as prescribed by the CAPS, surface vocabulary definitions were provided. For example, Teacher $\mathrm{C}$ (hereafter TC) in her lessons was teaching the topic "entrepreneurial qualities in business." At the start of the first lesson, learners received a handout with concepts relevant to the topic to be learned. TC commenced by reading out aloud the full definition of an entrepreneur from the Via Afrika Business Studies Grade 11 Study Guide (Chaplin et al., 2013).

An entrepreneur is someone who starts and manages or organises his/her own business and can either identify business opportunities to make new products or services or identify business opportunities to change existing products or services. (p. 132)

TC moved on to analyse the definition by pointing out that "the first thing . . . is that an entrepreneur is someone who first identifies and researches a business opportunity." She went on to say,

The first thing we've learned in this topic is that an entrepreneur is someone who first identifies and researches a business opportunity, then later starts his/her own business. In grade 10 we learned that business opportunities are divided into two ventures. What are those ventures?

The learners raised their hands and the teacher pointed to two of them to give the answers. L1 replied. "A person can either sell new or old products." L2 said, "Render services to his 
customers." The teacher followed this up by saying, "Let's clap hands for both of them as they are correct." The learners clapped their hands.

In this dialogue the teacher brings in prior knowledge that connects to the current topic. She continued the lesson by further clarifying the difference between the two types of business ventures mentioned in the learners' responses. She explained to the learners that some entrepreneurs can offer both goods and services in their businesses. This encouraged the learners to give their own examples, which led to a short class discussion. She provided opportunities for students to understand the two types of business ventures.

The handout contained other related concepts such as "opportunity-seeking", "perseverance", and "risk-taker," and these terms appeared below the key concept. TC moved onto a discussion of these qualities of an entrepreneur. She analysed the qualities of perseverance with the learners. She asked, "What is perseverance? A learner replied, "Simply means not giving up." The teacher asked if anyone had a different answer and a learner said, ". . . to continue in a course of action under difficult circumstances." The teacher responded by saying, "I think I like that one." She went on to ask, "What are the synonyms of perseverance?" One learner offered "continue" and another said, "persist." Here we can see that several opportunities were provided for learners to grasp the meaning of perseverance as an entrepreneurial quality. TC introduced and defined what an entrepreneur is, spoke about the two types of business ventures, and discussed the qualities of an entrepreneur. Through exposition and analysis, she presented definitions of key concepts and their attributes.

In going further than merely explaining the vocabulary definition of the qualities of entrepreneurship, TC could have provided more examples of different entrepreneurs. The support provided by government structures or private companies should have been included. Learners may then realise that perseverance is just not an individual or innate quality but is also dependent on the social structures that enable it. For inferential thinking to be practised learners require a range of examples from which they deduce the generalisation and its justification. They need to know the empirical variations and complexities that arise in different cases and contexts.

Teacher D (hereafter TD) was teaching the concept of citizenship roles and responsibilities and the sub-concepts of social responsibility, corporate social responsibility, and corporate social investment. In this lesson she began by reading the definition outlined in the Gauteng Education Department's Business studies grade 12 notes on CSR and CSI $2019^{1}$

Social responsibility [is] an ethical viewpoint that says every individual/organization has an obligation to benefit society as a whole. (p. 3)

She then went on to read from Chaplin et al. (2013)

The Gauteng Education Department's study guide notes are prepared by facilitators to ensure that learners access the same content across the board. They are meant to ensure that teachers do not use outdated textbooks so are revised each year. Currently, these have not yet been published but, once finalised the notes will be rolled out to the whole country. 
Corporate social responsibility (CSR) is a company's sense of responsibility towards the community and environment (both ecological and social) in which it operates. (p. 136)

TD explained to the learners that businesses need to be involved with social responsibility projects to uplift the communities in which they operate. She informed students that social responsibility projects would be discussed later. TD then moved to on to read the definition of corporate social investment (CSI) in the Gauteng Education Department's Business studies grade 12 notes on CSR and CSI 2019. "Corporate social investment (CSI) is the investment of corporate funds/other assets for the primary purpose of achieving social outcomes" (p. 4).

In the lesson the definition of the concepts was read out and the teacher established the connection between concepts at a basic level only. The epistemic structure of the subject could have been developed in the section on citizenship roles and the two types of responsibility_corporate responsibility and corporate social responsibility. In each, examples ought to have been provided for concept formation to be enabled.

Inferential thinking refers to helping learners make inferences when information is implied rather than being stated directly. Since the teacher either read out the textbook definitions or learners were given information by the teacher, inferential thinking was not activated in any of the lessons we observed. TC read out all the concepts together with their definitions in the handout. Similarly, the other teachers observed in this study also read out the definitions of concepts in the textbook. For deep learning to occur McPhail (2020) has advised teachers to identify concepts in the current topic and to encourage learners to make inferential connections.

For inferential reasoning to be activated learners derive the variations in characteristics of the concept by analysing content, such as case studies, on their own. To justify their generalisations, they cite proof. For example, for the generalisation that entrepreneurs start off with very little capital, a learner might cite by way of proof that the Airbnb business was founded by its originator, Brian Chesky, who needed money to pay his rent. The Airbnb's business began when Chesky accepted a boarder who provided the required money.

The focus on everyday knowledge also detracted from the focus on the concepts and the epistemic structure of the subject. For, example, TA set a task on business roles individuals play in their communities. Of the three learners who read their work out, the first learner's presentation is reproduced below.

As an individual I have a responsibility to make sure that the environment I live in is protected. During school holidays my friends and I make sure that we clean local parks by collecting bottles and tins that people litter on the grounds. We place plastic bags around the park and show people where they need to [put] their waste. We also teach kids about the effects of littering [on] the environment. We show them around the park how [the] littering of bottles, tins, and plastics cause damage [to] the grass and future growth of the grass and other plants. 
This learner was followed by others who read out their paragraphs that indicated similar community related work in which they engaged.

\section{Connecting concepts to content}

Data analysis of the lesson transcripts showed very little engagement with content that illustrated the meaning of the concepts. It was only TC who identified an appropriate example for learners to conceptualise the meaning of two types of business ventures. She gave the example of a salon owner who offers hair services to her customers, and, at the same time, sells hair products inside the salon. The learners could see the connection between the concept of a business venture and a local example that would enable them to grasp the meaning of the concept.

The dominant practice we observed on the part of the learners was the copying of notes that the teacher wrote on the board or the copying of notes from the textbook or study guides. The dominant practice of teachers was reading out aloud definitions of concepts from the study guides.

For example, TB started the lesson by instructing the learners to copy down the definitions from the textbook, Platinum business studies. Grade 11, learner's book (Pinnock et al., 2012) into their note books as she wrote these on the board. TB copied the definitions exactly as they appear in the textbook.

When learners had copied the notes, TB introduced the lesson by reading the definitions out aloud. She then informed the learners that these definitions needed to be learned and memorised for exam purposes. The lesson conducted by TB was dominated by the copying down of notes. During the lesson, she did not provide appropriate content nor examples to enable any understanding of the concepts to take place. Her main practice was writing notes on the board. Question and answer sessions and class discussions were not evident in the lesson conducted by TB.

The topic presented by TA was on citizenship roles and responsibilities. She began by reading a list of definitions outlined at the beginning of the chapter in the textbook. Learners highlighted or underlined the definitions in their textbooks as TA defined the two main concepts of social responsibility and corporate social responsibility.

After reading out these concepts, TA emphasised to the learners that the definitions needed to be memorised for the term 3 controlled test. TA explained to the learners that the social responsibility projects would be dealt with in greater detail in the grade 12 syllabus. She then continued with citizenship roles and responsibilities, saying, "now that you are aware of the difference (between social responsibility and corporate social responsibility), we will now discuss the citizenship roles and responsibility towards stakeholders. Lebo, can you read the first passage for us." 
All four teachers read out definitions from the textbook or study guide to learners or got the latter to read them out aloud. The extent to which teachers read out definitions and/or got learners to copy them down was greater in TA's and TB's lessons.

TD taught three concepts (social responsibility, corporate social responsibility, and corporate social investment) under the topic of citizenship roles and responsibilities without examples or content.

Furthermore, all the teachers observed bypassed the content provided in the textbooks they were using. For example, this case study in the Via Afrika business studies grade 10 learner's book (Bean et al., 2013, p. 115), ${ }^{2}$ that deals with a local entrepreneur's enormous success could have been engaged with during the lesson.

\section{Case study: Ina Paarman's story}

Ina Paarman inherited her love of food and cooking from her grandmother who was an enthusiastic cook. Ina started working with food by offering cooking classes at night in the garage of her house. The classes were soon popular and Ina branched out and began to make her own ingredients.

Originally, she made mostly salad dressings and sauces, but this meant that she mostly had a summer market. She therefore diversified her range and also began to export to Europe and the United States.

Today, her son, Graham, works with Ina. Ina formulates the recipes for the products and Graham manages the factory and the finances. Ina believes that a closely knit family is a good basis for a successful business.

Furthermore, the useful activity that appeared below the case study, based on this case study, that appears in Chaplin et al. (2013, p. 203), was also not addressed by any of the teachers.

Discuss reasons for being an entrepreneur. Work in groups and discuss the following statement: "Among the people who become entrepreneurs, many are doing so because they cannot find employment in the formal sector of the economy."

Furthermore, this case study could have been analysed for other business processes such as diversification, seasonal market fluctuations, and the export of products. More case studies of different types from various sources could have been provided for learners to use to analyse, gather data, and develop a data table.

The literature on pedagogy for concept formation shows that concept formation cannot happen without appropriate content and examples. Data analysis shows that teachers have difficulty with the key requirement of identifying and including appropriate content material Teachers use the resources available to them and most of the learners would have been familiar with the content of
this grade 10 book. 
to clarify the meaning of concepts. This leads to teachers reading out textbook content and definitions of concepts as vocabulary words to learners. Pedagogically, it amounts to telling learners the definition of concepts in a "bare-bones" way (Parker 2020, p. 1). Learners were not provided with content that required them to analyse and infer meanings and make generalisations. The lack of appropriate examples of entrepreneurs about whom students could infer deep conceptual knowledge reduced the deep learning opportunities for them.

None of the teachers included content about the history of knowledge production to show that ideas are always provisional and subject to challenge and change. For example, both concepts of CSR and CSI are recent additions to business studies. Learners need to know this history of how knowledge is produced since being ignorant of this leads them to accept knowledge as given, objective, and universally true. Additionally, the contents of the textbook ought to have been subjected to critical scrutiny.

There was no evidence in the lessons of content material aimed at meeting the social and political interests of learners. The lack of differentiation of knowledge and information about different levels of entrepreneurship denied learners the opportunity to learn about future opportunities as entrepreneurs.

\section{Connection of knowledge-that (KT) to knowledge-how (KH)}

The third element of the model requires that teachers connect $\mathrm{KT}$ to $\mathrm{KH}$; learners must be able to apply the knowledge they have learned. This includes performance and the judgement competencies to solve practical and theoretical problems. Since the mediation of KT occurred only at surface level, any connection to KH was necessarily superficial as well. Linking KT to KH is vital for learners' understanding and for application to their everyday lives. This linking activates everyday or common-sense knowledge, examples of which could provide a good starting point, but this needs to be expanded to include other examples as well.

Successful entrepreneurs in the community, for example, could provide authentic examples to the learners of each entrepreneurial quality in relation to personal experiences, challenges, and threats, and how problems were solved. Both topics, entrepreneurial qualities and entrepreneurial corporate responsibility, were dealt with only at the level of definition. Learners were not required to exercise performance and judgement competencies. Activities and exercises were limited in all classrooms. In TB's lesson, learners were given a homework activity from the textbook, as part of their formative assessment. TB did not demonstrate to the learners how the key concepts of the topic listed in the textbook and read out at the beginning of the lesson could be applied in a real-life situation, and in different contexts. For instance, the owner of the school tuck-shop could have been invited to share real life experiences of running a business and thus give the learners a chance to ask questions addressed to an entrepreneur whom they know.

Although the learners were seated in groups in TA's class, no discussion at all ensued during the lesson. In one lesson, the teacher recited definitions of the following business roles in detail: social responsibility; environmental sustainability; economic prosperity; product 
stewardship; procurement; product access and dualistic economy; apartheid legacy; and poverty and HIV/Aids. The following excerpt illustrates the direct instruction technique she used. She said,

Learners, it is very important to note that business owners have a mandate to assist the government to uplift communities they operate in. Let's look at each role the businesses play. The first role: social responsibility: What is CSR under Social Responsibility? Corporate social responsibility (CSR) is a company's sense of obligation towards the community and the environment (both ecological and social) in which it operates. There are many factors that contribute to local communities requiring social responsibility from the government and the businesses. Factors such as inequalities of the past, the ever-increasing population growth, lack of adequate skills which leads to high unemployment. Therefore, businesses have a mandate to bring change in the communities they operate in, because the government cannot do it alone. Businesses can reduce poverty by donating money or food parcels to the needy and orphanages. Also, give away bursaries to those students who wants to further their studies. Also organise health awareness campaigns that teaches about HIV/AIDS. Please note that businesses spend their profits when they get involved in uplifting their communities. How else can businesses get involved?

A learner responded, "In order to reduce poverty businesses can create more jobs and hire more people in the community, while equipping them with skills."

TA then said, "Very good. Businesses can also support sporting tournaments. Let us move to business role number 2. The second role is Environmental sustainability." She did not show the learners how the key concepts of the topic could be applied in a real-life situation. For instance, she could have discussed a case study that depicted real-life local initiatives in which the local businesses engage to improve the local communities, or she could have shown a video portraying corporate social responsibility programmes. In a nutshell, the learners were not provided with any content to facilitate their concept formation. They were not given a chance to apply the learned concepts and content to other contexts during the lesson. In all lessons, learners were not required to read, analyse, gather, and organise data.

Three of the four teachers did not provide learners with opportunities for evaluation and validation of understanding of concepts. The further requirement of curriculum design for deep learning to provide ongoing evaluative and constructive feedback that helps students to complete the task successfully as part of the learning process was not evident.

All that was required of the learners was to read from the textbook and/or study guide, listen to the teacher read from the textbook, and jot down notes. Evaluative and constructive feedback was not provided by the teachers to assist them through tasks to consolidate concept formation. 


\section{Evaluation of knowledge-that (KT) and knowledge-how (KH)}

This element of the model requires the teacher to evaluate knowledge-that (KT) and knowledge-how $(\mathrm{KH})$ through competencies like content recall, skill and technique, intelligent know-how, and knowing why. The first competency of recall requires evaluating whether learners remember the content. All four teachers did evaluate the learners' recall competency. For example, as noted above, TC asked questions to assess learners' understanding but there was no progression to questions that would evaluate higher order skills and techniques and understanding such as generalisation, justification of generalisation, and the application of conceptual knowledge. The evaluation of skills and techniques was not evident. Learners 's understanding of concepts was not tested through generalisation and the application of conceptual knowledge. Justification of their application that validates, in turn, a higher level of understanding was also not evaluated.

\section{Discussion}

The lessons showed that key concepts had been selected and sequenced in a logical way. This finding is similar to that of Hoadley (2018) who noted stronger classification of subject knowledge in her research on pedagogy in lessons on reading and numbers. The explicit prescriptions in the CAPS policy of concepts to be taught and reinforced by the annual teaching programme (ATP) that outlines topics and concepts and is monitored by the heads of departments are undoubtedly supporting teachers in the selection and sequencing of concepts.

The pedagogical practice of teachers that ranged from direct instruction in the defining of concepts, reading definitions out aloud, and copying notes from the chalkboard hindered deep conceptual learning from occurring in learners. Cappy (2016), in her study of teachers in South African secondary schools, found evidence of a similar pedagogy being in place. She found that the most common practice was narrative instruction or telling students what to think and how to act. Direct instruction, narration, and telling students what the definitions consist of are ineffective strategies to achieve deep conceptual learning. This kind of direct instruction by teachers is similar to the lecture method that Aamna (2017) found to be ineffective for concept formation. Bender and Schreiber (1980) noted that this traditional form of instruction by definition is pedagogically and epistemologically problematic for concept formation. This study provides further evidence of Ramnarian's (2014) findings that teachers at township schools, an example of which is referred to as an LSES school in this study, have a strong active direct teaching orientation overall instead of a guided inquiry orientation, with concepts being developed via a guided exploration phase. Furthermore, in most of the lessons, the teachers in this study did not elaborate on the definitions nor did they analyse them at all. Failing to identify and establish attributes of the concept served to make its knowledge structure invisible as Bernstein (1999) pointed out in his theory of social class and pedagogic practice. The epistemic structure remained implicit since vertical and horizontal interconnections were not explicitly pointed out. 
The common practice of the teachers in this study of reading definitions out loud accompanied by supplemental instruction hindered higher-level thinking and cognitive advance in their learners. This practice of reading aloud textbook knowledge seems to be quite common in South African classrooms. Cappy (2016) wrote about a Life Orientation teacher who asked learners to read aloud while simultaneously instructing them on the social consequences of pregnancy.

Another practice that hindered higher level thinking skills and cognitive advance in the learners was their having to copy down notes from the textbook, study guide, or the chalkboard. The practice of such copying down of notes was also highlighted in studies by Cappy (2016), Hoadley (2018), and Probyn (2017). Probyn (2017) researched language and learning in South African classrooms and noted the practice of "teachers resorting to writing up simplified notes on the chalkboard for students to copy" (p. 28) that would compromise linguistic access, equity, and social justice. Hoadley (2018) also found copying notes to be common in the classrooms she observed. Cappy (2016) observed that when teachers covered topics of democracy and human rights, they frequently had students copy down notes without supplemental discussion. Their lessons focused on the memorisation of terms rather than on how such concepts can be practised. The practices of direct instruction or telling the learners the names of the concepts, reading aloud from the textbook, and copying notes will not lead to deep learning since "deep learning requires actively pursuing meaning, searching for patterns and underlying principles, evaluating conclusions, examining arguments carefully, and becoming actively interested in subject knowledge" (Hattie \& Donoghue, 2016, p. 3).

The second element of connecting concept to content was not evident in any of the lessons. Given the lack of appropriate learning experiences - a principle of curriculum design (Tyler, 1949) - the understanding of concepts is jeopardised. Although content in the form of case studies and activities was provided in the textbook and study guide, these teachers did not include them in their lessons. The lack of appropriate content and examples that would enable concept formation restricted any deep conceptual learning from taking place in the learners. Inferential reasoning was not expected of them.

The distinction between surface and deep structure of knowledge enables understanding of the form of knowledge that was mediated in the lessons. In her book, Pedagogy in poverty, Hoadley $(2018$, p. 4) characterised an "enduring" feature of pedagogy in the South African classrooms she researched as "the knowledge substance underpinning the pedagogy [being] thin or absent." Teachers "mimic the surface characteristics of the task" (MacDonald, 2002, cited in Hoadley, 2018, p. 4). Smith and Colby (2007) concluded that teacher participants in their study lacked knowledge of deep learning approaches and settled to teach at surface levels which led to their learners demonstrating surface outcomes instead of deep learning ones. Because such findings were common among their communities of teachers and learners, they proposed that "teachers need to understand, value, and foster deep approaches to learning in their students" (p. 205).

It would appear, as mentioned earlier, that teachers are focusing on what Parker (2020) referred to as "bare-bones definition" without "adding flesh" by failing to provide 
opportunities for learners "to also know vivid examples of the concept" (p. 1). The lack of content and examples that would facilitate concept formation further prevented deep conceptual learning from taking place.

A possible explanation could be that teachers have difficulty in identifying appropriate subject content and examples that would provide opportunities for learners' concept formation. It could be that the four teachers whose lessons we observed do not see the value of subject content as a way of enabling understanding of a concept or they are of the view that providing appropriate content and examples slows down curriculum coverage. A possible explanation for mediating the definitions in such a narrowly restricted way could be that the textbook and the notes from the local governing district lists the concepts and definitions in the same way thus legitimizing teachers' surface level mediation of knowledge. Another possible explanation is that these teachers all teach towards examination and test preparation. In TD's case it was evident that content knowledge was lacking, and this is yet another possible explanation.

Our results show that these teachers might be having difficulty with the key requirement of identifying appropriate content and examples that support concept formation. The readymade department lesson plans should include content and examples or case studies for teachers to use. Without appropriate content that requires analysis and inferential thinking deep conceptual understanding will not be enabled in the learners.

These results suggest that most of the learning in these grade 11 business studies classrooms is characterised by surface learning, as Hoadley (2018), in her study of foundation phase classrooms, noted.

The absence of engagement with content introduces incoherence across subject concept and the third element of connecting KT to KH becomes impossible. The teachers in this study did not include opportunities for learners to solve practical and theoretical problems.

Furthermore, in the evaluation step, the evaluation of KT occurred at the basic level of recall while the evaluation of techniques and methods and the application to a variety of contexts (KH) was lacking.

\section{Conclusion}

We conclude that limited opportunities for deep conceptual learning and cognitive advance were provided in these business studies classrooms. In terms of the CDC model the incoherence across the four elements of subject concepts, subject content, subject competencies, and assessment disrupted deep learning opportunities. Instead of coherence across the four elements we found elements two and three to be absent. Coherence was evident across the first element - subject concepts - and the basic part of element fourevaluation of KT - at the fundamental level of recall of definitions. The dominant practices of direct instruction, reading textbook definitions, and having learners copy down notes displaced elements two and three as well as advanced levels of element four. Since the dominant practices have also been highlighted by other researchers, as discussed above, it is 
imperative that attention be paid to teachers' own depth of understanding of subject content knowledge and pedagogical knowledge of deep conceptual learning. Since deep learning requires teachers to have a panoramic overview of the subject as noted by Winch (2017) in McPhail (2020), for them to be able to teach it well, some effort ought to be made to deepen teachers' subject content knowledge. We recommend interventions to improve teachers' capability of teaching for deep conceptual learning based on selecting appropriate content to facilitate concept formation. Furthermore, digital resources on the internet could be included in their cognitive horizon (Hoadley, 2018) to supplement what is in the textbooks. However, more research is required to establish how widespread the difficulty with selecting appropriate content and examples to enable concept formation is for business studies teachers.

The CDC model enables a systematic analysis of different pedagogic processes that contribute to deep conceptual learning. It goes further than general descriptions such as learner-centred and teacher-centred pedagogy into a more detailed analysis of the four epistemic dimensions that require coherence/connection across subject concepts, subject content, subject competencies, pedagogy, and assessment.

\section{References}

Aamna, I. (2017). Concept formation teaching model: An innovation in teaching. GATR journals. Global Academy of Training and Research Enterprise. https://ideas.repec.org/p/gtr/gatrjs/jmmr125.html

Albert, E., \& Van Der Mark, M. H. (1981). The effect of peer teaching on concept formation and attitude change of student teachers. Science Education, 65(2), 179-186. https://onlinelibrary.wiley.com/doi/abs/10.1002/sce.3730650208

Ark, V. T., \& Schneider, C. (2016). Deeper learning for every student every day. Gettingsmart.com

Aufschnaiter, C. V., \& Rogge, C. (2012). Conceptual change: A powerful framework for improving science teaching and learning. International Journal of Science Education, 25(6), 671-688.

Babbie, E., \& Mouton, J. (2006). The practice of social research. Oxford University Press.

Bean, P., Kleyn, M., Llewellyn E. L., Maliehe T. R., Marx, A., \& Kotze, T. (2013). Via Afrika business studies grade 10 learner's book. Via Afrika.

Bender, P., \& Schreiber, A. (1980). The principle of operative concept formation in geometry teaching. Educational Studies in Mathematics, 11, 59-90.

Bernstein, B. (2000). Pedagogy, symbolic control and identity. Rowman and Littlefield. 
Cappy, C. (2016). Shifting the future? Teachers as agents of social change in South African secondary schools. Education as Change, 20(1), 28-42. http://dx.doi.org/10.17159/1947-9417/2016/1314.

Chaplin, C., Llewellyn, E. L., Bean, P., Kleyn, M., Marx, A., Kotze, T. D., \& Maliehe, T. R. (2013). Via Afrika business studies grade 11 study guide. Via Afrika.

Collis, B, Wang, C., Rowe, G., \& McPhail, G. (2017, December). Towards an informed course design. Paper presented at the meeting of the Association of Australian Engineering Education (AAEE), Sydney.

Department of Basic Education (DBE). (2011). Curriculum and Assessment Policy Statements: Business Studies: Further Education and Training Phase Grades 10-12. Department of Basic Education. https://www.education.gov.za/Portals/0/CD/National\%20Curriculum

Gouws, E., \& Russel, Y. (2013). Assessment for learning: A case study in the subject business studies. Journal for New Generation Sciences, 11(1), 74-88. https://journals.co.za/content/newgen/11/1/EJC141431

Hattie, J., \& Donoghue, G. (2016). Learning strategies: A synthesis and conceptual model. Science of Learning, 1(16013), 1-13. https://www.nature.com/articles/npjscilearn201613

Hoadley, U. (2018). Pedagogy in poverty: Lessons from twenty years of curriculum reform in South Africa. Routledge.

Jensen, E., \& Nickelsen, L. (2008). Deeper learning: 7 powerful strategies for in-depth and longer lasting learning. Corwin Press.

Kispal, A. (2008). Effective teaching of inference skills for reading. National foundation for educational research. https://www.nfer.ac.uk/publications/EDR01/EDR01.pdf

Marzano, R. J. (2010). The art and science of teaching / teaching inference. http://www.ascd.org/publications/educationalleadership/apr10/vol67/num07/Teaching-Inference.aspx

McPhail, G. (2020). The search for deep learning: A curriculum coherence model. Journal of Curriculum Studies. https://doi.org/: 10.1080/00220272.2020.1748231.

Meintjies, A., Henrico, A., \& Kroon, J. (2015). Teaching problem-solving competency in business studies at secondary school level. South African Journal of Education, 35(3), 1-11. https://www.ajol.info/index.php/saje/article/view/121855 
Muhle, M. S. (2014). The implementation of the CAPS by grade ten Business Studies teachers at two particular high schools in the Ugu District (Unpublished doctoral dissertation). University of Kwa-Zulu Natal, Durban, RSA. http://ukzndspace.ukzn.ac.za/handle/10413/12587

Parker, W. (2020). Concept formation. https://teachinghistory.org/teachingmaterials/teaching-guides/25184

Pinnock, A., Strydom, J., \& Viljoen, A. (2012). Platinum business studies. Grade 11, learner's book. Maskew Miller Longman.

Probyn, M. (2017). Languages and learning in South African classrooms: Finding common ground with north/south concerns for linguistic access, equity, and social justice in education. In P. Trifonas \& T. Aravossitas (Eds.), Handbook of research and practice in heritage language education (pp. 1-19). Springer. https://doi.org/10.1007/978-3-319-38893-9_28-1

Ramnarian, U. (2014). The pedagogical orientations of South African physical sciences teachers towards inquiry or direct instructional approaches. Research in Science Education, 44(4), 627-650.

Shulman, L. S. (1986). Those who understand: Knowledge growth in teaching. Educational Researcher, 15(2), 4-14.

Sithole, B. M. (2018). Making group-work work: Ideas for teaching business studies derived from Kagan's cooperative learning structures. International Journal of Educational Sciences, 22(1/3), 11-18. http://krepublishers.com/02-Journals/IJES/IJES-22-0-00018-Web/IJES-22-1-3-000-18-Abst-PDF/IJES-22-1-3-011-18-1063-Sithole-B-M/IJES22-1-3-011-18-1063-Sithole-B-M-Tx[2].pmd.pdf

Sithole, B. M., \& Lumadi, M. W. (2012). Pedagogical challenges besetting business studies teachers in secondary schools: A Botswana perspective. Journal of Social Sciences, 32(1), 71-80. http://www.ijsre.com/assets/vol.\%2C-10(3)-complete-issues.pdf

Smith, T. W., \& Colby, S. A. (2007). Teaching for deep learning. The Clearing House, A journal of Educational Strategies, Issues and Ideas, 80(5), 205-210. https://www.tandfonline.com/doi/abs/10.3200/TCHS.80.5.205-210

The Hewlett Foundation. (2016). Deeper learning alliance for excellent education. www.hewlett.org/deeperlearning https://hewlett.org/wp-content/uploads/2016/08.

The William and Flora Hewlett Foundation. (2013). Deeper learning competencies. http://www.hewlett.org/uploads/documents/Deeper_Learning_Defined_April_2013. pdf, November 2013. 
Thomson, S. B. 2011. Qualitative research: Validity. Journal of Administration and Governance, 6(1), 77-80.

Tyler, R. (1949) Basic principles of curriculum and instruction. University of Chicago Press. 